\title{
Values, Ethics and Theoretical Perspectives of the Hartford Social Competency Scale-II: Factorial Structure and Reliability of a Portuguese Version
}

\author{
Fernanda Daniel (10) ${ }^{1,2, *}$ and Helena Espirito-Santo (1) ${ }^{2,3}$
}

\footnotetext{
${ }^{1}$ Centro de Estudos e Investigação em Saúde da Universidade de Coimbra, Coimbra, Portugal

${ }^{2}$ Instituto Superior Miguel Torga, Coimbra, Portugal

${ }^{3}$ Centro de Investigação em Neuropsicologia e Intervenção Cognitiva e Comportamental, Universidade de Coimbra, Coimbra, Portugal
}

*Correspondence to Daniel F, Rua Augusta, 46, 3000-061, Coimbra, Portugal. E-mail: fernanda.b.daniel@gmail.com

\begin{abstract}
Social work practice with the older population demands assessing gerontological competencies, for which values and ethics are central. This study aimed to test the adjustment of the Portuguese version of the Hartford Geriatric Social Work Competency Scale II subscale-values, ethics and theoretical perspectives (GSWCS-II-VEPT) to a bifactor structure and to analyse its reliability in a sample of social workers. The study enrolled 534 social workers employed in older adults' care organisations. The confirmatory factorial analysis showed that the items presented factorial loads more than 0.60 , and the bifactorial component model fitted well with the data. The two components consisted of 'nuclear competencies' and 'specialised skills'. The GSWCS-II-VEPT presented excellent reliability (Cronbach's $\alpha=0.90$ ). However, high interfactor correlations demanded the test of a single-factor solution. The single-factor model did not fit the data as well as the two-factor solution, and the Akaike information criterion value was smaller in the two-factor model, indicating a superior fit. The results support adequate psychometric properties of GSWCS-II-VEPT in evaluating ethical skills, values and theoretical perspectives in Portuguese social workers and can be used as a tool for self-evaluation of these professionals' ethical behaviour.
\end{abstract}

Keywords: aging, assessment, competencies, ethics, gerontology

Accepted: September 2021 


\section{Introduction}

The growth of the ageing population coupled with the fact that social workers are working with this population segment requires specialised expertise and skills. In the literature (Rosen and Zlotnik, 2001; Rosen et al., 2003; Damron-Rodriguez et al., 2006), it is recognised that it is crucial that social workers master specialised knowledge and skills to work with older people and that these aspects are adequately assessed. The Geriatric Social Work Competency Scale-II (GSWCS-II) is the first instrument designed and validated to assess knowledge and skills regarding older people. The aspects assessed by the scale include the domain of values, ethics and theoretical perspectives (VETP) (DamronRodriguez et al., 2006, 2009). Values and ethics are essential to the social worker's practise, so our study focuses on validating this domain independently. Some studies that investigated other domains of the GSWCSII (Bonifas and Simons, 2014; Daniel et al., 2018) found that they had a bi-factorial structure. Thus, in our study, we used confirmatory factor analysis (CFA) to test a hypothetical two-factor structure of the subscale of the VETP domain of the GSWCS-II (GSWCS-II-VETP) in a sample of social workers working with older people residing in care institutions.

\section{Review of the literature}

The exercise of a profession assumes sharing a set of values, principles and ethical obligations. Values and ethics are central in social work, as the analysis of the profession's history demonstrates. According to Reamer (2017), social workers have always been concerned with questions about right and wrong and about duty and obligation throughout social work history.

The experimental code of ethics is attributed to Mary Richmond, one of the pioneers of social work, and was published in 1920 (Casimir and Samuel, 2015). From that time to the present day, social workers' concerns with ethics have changed from moralistic concerns to those related to the complexity of ethical dilemmas (Reamer, 2017) in a space where professional intervention has a relative autonomy (Mioto and Nogueira, 2013).

According to Reamer (2013), it is possible to trace the evolution of social service values and ethics, sometimes with overlapping periods:

1. period of morality-attention focused mainly on the morality of the client, rather than on the morality or ethics of the profession or its practitioners;

2. period of values - the interest in the morality of the users was overlooked by the concerns related to the fundamental values of the profession; 
3. period of ethical theory and decision making - a significant transition from when social workers focused on values when ethical issues joined attention about values. In this period, the relevance of moral philosophy and ethical theory in the ethical dilemmas faced by social workers was explored;

4. period of ethical standards and risk management—negligence and professional liability were problems that emerged at this time, both because of the growth in the field of professional ethics and because of complaints and disputes related to professional intervention;

5. digital period - as social workers increasingly use a wide range of digital and other electronic technologies, new problems began (privacy, confidentiality, informed consent, conflicts of interest, etc.).

For Banks (2004), the trends observed in social policy have implications in the organisation of the practice and ethics of social work they are: (i) privatisation and the increasing role of the market in social care; (ii) fragmentation and specialisation of social work; (iii) growth of multidisciplinary working; (iv) decline in public trust among professionals and interest for more responsibility; (v) rise of the 'consumer' movement and the need for service user and community participation ('consumerism' and 'radicalism'); (vi) growing awareness of citizens' responsibilities ('communitarianism'); and (vii) questioning of universal values ('post-modernism').

Along with the reconfiguration of ethical concerns and new ethical dilemmas, there is a significant change in the demographic profile worldwide. In the sixth census of Portugal's population on 1 December 1920, there were 9.4 percent individuals over sixty years old compared to 25.0 percent of Portugal's last census (Instituto Nacional de Estatística, 2013). The world's population $>60$ years of age is growing at $\sim 3.0$ percent per year (Nações Unidas-ONU Portugal, 2019).

Concomitantly, with this increase in the number of older people, there have been important changes in family structures, which have resulted in an increase in intergenerational relations and a decrease in intragenerational relations (Vicente and Sousa, 2012). Thus, new family arrangements became significant, with a slight decrease in the dominant pattern of a couple with children and increased one-person and single-parent families (Carvalho and Almeida, 2003). These changes are in line with the mobility of geographical and socio-professional itineraries and with women's labour market participation that has impacted older people's family and social framework (Daniel et al., 2018).

As a result of these transformations leveraged by the ageing of the population, social workers were called upon to respond to the needs of this population segment that is growing rapidly. In this sense, the National Association of Social Workers (NASW, 2020a,b) states that the older population's significant increase is recognised both as a challenge and as a social worker's opportunity. Furthermore, preparing social 
workers to practice with the older population requires identifying gerontological competencies for the profession (Damron-Rodriguez et al., 2006).

In this regard, Scharlach et al. (2000) point out that social workers can bring unique contributions to older people and their families. Tuncay and Duyan (2015) agree with this idea, recognising that social workers' theoretical perspectives and skills are indispensable for improving the well-being of older people. However, integrating systematic gerontological educational programmes into social workers' curricula is essential for these competencies (Peterson, 1990; Rosen et al., 2000; Damron-Rodriguez et al., 2009).

According to the results of a survey conducted in the USA with NASW members, the knowledge and competencies in ageing were minimal at the end of the 20th century. In that survey, social workers mentioned that gerontological knowledge is necessary regardless of if they worked with the older population or not (Peterson, 1990). In this context, the GSWCS-II emerged with the support of the 'Council on Social Work Education-Gero-Ed Center Competency Goals' and the 'Hartford Partnership Programme in Aging Education'. The scale development stemmed from an extensive gerontological social work literature review and a panel of gerontologists, researchers and social workers. The final questionnaire was distributed to 2,400 social workers, teachers and researchers (Damron-Rodriguez et al., 2009).

\section{This study}

After adapting GSWCS-II to Portuguese, we will present, in this article, the results of the administration of the GSWCS-II-VETP to social workers who regularly work in care institutions for the older population. The overall aim of our study was to test the fit of the GSWCS-II-VETP. Given that two studies point out a bifactorial structure ('Core Geriatric Intervention Practice Behaviors' and 'Specialized Geriatric Intervention Practice Behaviors') in some GSWCS-II domains (Bonifas and Simons 2014; Daniel et al., 2018), we will explore a bifactor structure and reliability of the GSWCS-II-VETP in a sample of social workers.

\section{Methods}

\section{Participants}

The sample $(N=534 ; 513$ female and 21 male) was composed of social workers who worked in private for-profit and not-for-profit organisations aimed at the older population in Portugal mainland. The criteria for 
participation required a degree in social work and gerontological experience.

\section{Instruments}

\section{Sociodemographic and professional questionnaire}

We asked about sex, age, years of gerontological experience, job category, post-graduate studies and juridical form of the work institution.

\section{GSWCS-II-VETP}

GSWCS-II-VETP is the first of five domains of GSWCS-II, assessing social workers' competencies working with the older population. GSWCSII-VETP was developed based on the recognition that social workers have the knowledge and competencies to apply multidisciplinary and multidimensional assessment methodologies when working with older adults (Damron-Rodriguez et al., 2006). GSWCS-II-VETP includes ten items that could theoretically be grouped into two factors as in Bonifas and Simons' (2014) study with two other domains of the GSWCS-II. The first five items belonging to factor 'Core geriatric assessment Practice Behaviour' (e.g. Item 1. 'Assess and address values and biases regarding aging') and the remaining items to factor 'Specialised geriatric assessment practice behaviours' (e.g. Item 6. 'Relate concepts and theories of aging to social work practice'). Items are answered on a five-point Likert scale, ranging from zero 'Not skilled at all (I have no experience with this skill)' and four 'Expert skill (I complete this skill with sufficient mastery to teach others)'. Subscale total score can vary between zero and forty points (expert).

\section{Procedures}

The translation and adaptation of the GSWCS-II-VETP Portuguese version followed Hambleton et al. (2005) and International Test Commission (2017) guidelines. Thus, the GSWCS-II-VETP was forward-backwards translated: the questions and instructions were translated into Portuguese by two English fluent, independent researchers. Where inconsistencies were found, these were corrected after discussion with experts (ethics professor in social work courses). A final translated version was given to an independent native speaker blinded to the original questionnaire and translated back into English. A high level of correspondence (International Test Commission, 2017) between the two versions was obtained. 
To judge the appropriateness of the language used, the final version of the GSWCS-II-VETP was then administered to four social workers acting in the gerontological area, who reported no problems in the intelligibility of questions and instructions.

Recruitment started with the Carta Social's browsing (Gabinete de Estratégia e Planeamento do Ministério do Trabalho, Solidariedade e Segurança Social, 2020), looking for email addresses of Portugal mainland organisations focused on older adults. 'Carta Social' is an official website of the Portuguese government (https://bit.ly/3AazL0a) where it is possible to search for data regarding the institutions that provide social support in the mainland of Portugal. Three thousand six hundred and fifteen organisations were identified, including social centres, daycare centres, night-care centres, nursing homes and home support services.

\section{Ethics statement}

The Instituto Superior Miguel Torga Ethics Committee approved this study. The research was considered low risk to participants since contribution was voluntary, replies were confidential and no identification was asked.

Through e-mail, we contacted institutions' boards to present the study objectives, asking to resend the link to social workers working in the institutions. In the e-mail, a link for a Google Docs form was provided. The form included informed consent before data collection and the possibility to withdraw consent and participation at any time.

\section{Statistical analysis}

Statistical analyses were performed using the Statistical Package for Social Sciences-SPSS for Windows (IBM SPSS, version 26). Descriptive statistics were tabulated for sample sociodemographic and professional characterisation.

Model fit was tested by running a CFA of the GSWCS-II-VETP employing BM SPSS Amos for Windows version 26. Parameters reported were the weighted least square parameter estimates using a diagonal weight matrix (Kline, 2015). CFA assumptions on data were examined: minimum sample size, absence of multicollinearity and singularity (analysis of $R$-matrices), normality of data (analysis of univariate kurtosis and skewness, $\mathrm{SK}<|3|$ and $\mathrm{Ku}<|7|)$ and absence of serious violations regarding multivariate outliers (analysis of Mahalanobis $D^{2}$ distances) (Kline, 2015). 
To test the hypothesised bifactor structure, we analysed the items and grouped them similar to the bifactor structure in the two domains of the GSWCS-II by Bonifas and Simons (2014). Thus, each item was assumed to load only on its expected factor, and correlations between the two factors were permitted but not between item error terms. The maximum likelihood method was used for the model fitting. The most cited goodness-of-fit indicators were a priori chosen (West et al., 2012) and taking into consideration to cover absolute and incremental measures of fit (Hu and Bentler, 1999). Thus, we used the normed Chi-square ([only reported for descriptive purposes because of its limitations (Marsh et al., 1988)], the comparative fit index (acceptable if $\geq 0.90$ and good if $\geq 0.95$ ), the normed fit index (acceptable if $\geq 0.90$ and good if $\geq 0.95$ ), the standardised root mean residual (SRMR, good fit if $<0.05$, acceptable fit if $<0.08$ ), and the root mean square error of approximation (good fit if $<0.05$, acceptable fit if $<0.08$ and marginal if fit $<0.10$ ) (Browne and Cudeck, 1992; Hu and Bentler, 1999; Kline, 2015).

Considering previous studies with the global GSWCS-II that have focused on single-factor subscales (Gallagher et al., 2020) and the hypothesised intercorrelations between factors, we verified which was the most adequate model by comparing the adjustment indexes of single and bifactorial models. Adding to the indexes mentioned above, we also computed the Akaike information criterion (AIC; models with the lowest value are judged to fit the data better than alternative solutions; Byrne, 2016).

For reliability analysis, we calculated Cronbach's alpha (criterion $\geq 0.70$; Daniel et al., 2015), corrected item-total correlation (criterion $\geq 0.30$; Ware and Gandek, 1998), Cronbach's alpha if item deleted, and squared multiple correlations (criterion $>0.25$; Hair et al., 2009). We computed means and standard deviations, item-total correlations for item analyses. Moreover, items were considered to perform well if their standardised loadings were $>0.60$ (Garson, 2013).

\section{Results}

Details of the sociodemographic and professional characteristics of the sample are presented in Table 1. We highlight that most participants were female, ranging from twenty-two to sixty-three years old $(M=35.05 ; \mathrm{SD}=7.56)$. Regarding professional experience in the gerontology area, a mean of 9.02 years was found $(\mathrm{SD}=6.20)$, varying between less than a year and thirty-eight years. Adding to Table 1, among those that had a post-graduate study, 155 carried out post-graduate training (29.0 percent), 67 had a master's degree (12.5 percent) and 11 had a doctoral degree ( 2.1 percent). 
Table 1 Sociodemographic and professional characteristics $(N=534)$.

\begin{tabular}{lcc}
\hline Variables & $n$ & $\%$ \\
\hline Sex & & 3.9 \\
Male & 21 & 96.1 \\
Female & 513 & 16.9 \\
Professional categories & & 14.8 \\
Social worker a: first & 90 & 17.6 \\
Social worker: second & 79 & 21.3 \\
Social worker: third & 94 & 29.4 \\
Assistant social manager & 114 & \\
Otherb & 157 & 85.8 \\
Leadership functions & & 8.3 \\
Technical director & 332 & 4.7 \\
Coordinator & 32 & 1.3 \\
Service director & 18 & 56.0 \\
Service director/technical director & 5 & 43.6 \\
Post-graduate studies & & \\
No & 299 & 43.8 \\
Yes & 233 & 19.1 \\
Institutional juridical framework & & 13.9 \\
Social solidarity & 234 & 8.1 \\
Parish (social) centre & 102 & 5.2 \\
Irmandade da Misericórdia/Santa Casa da Misericórdia & 74 & 0.9 \\
Profit making entity & 43 & 0.6 \\
Social solidarity foundation & 28 & 8.4 \\
Religious organisation institute & 5 & \\
Mutualist association & 3 & \\
Other & & \\
& & \\
\hline
\end{tabular}

Note. ${ }^{a}$ The career of social workers is organised into five classes. ${ }^{b}$ Of this, 120 (76.4 percent) mentioned leadership roles, with the remaining describing diverse roles such as 'principal social work technician, without detailing the level.'

A tested two-factor model (Figure 1) indicated an acceptable fit to the data (Browne and Cudeck, 1992; Kline, 2015). Details of model fit are presented in Table 2. However, the estimated model correlation between the two factors was significant, positive and large $(r=0.76)$. For this reason, we also tested a single-factor solution, which did not fit the data as well (Table 2). This one-factor model presented fit indices indicating a poor model fit, except for SRMR that pointed to an acceptable fit. Furthermore, the AIC value was smaller in the two-factor model, indicating a superior fit.

Table 3 presents descriptive statistics, reliability coefficients and parameter estimates of GSWCS-II-VETP's items. The item presenting the highest mean score was Item 1 , 'Respect diversity among older adult clients, families, and professionals' $(M=3.38$; $\mathrm{SD}=0.56)$. The item showing the lowest mean score was Item 9, 'Support persons and families dealing with end-of-life issues related to dying, death, and bereavement' $(M=2.81 ; \mathrm{SD}=0.84)$. Corrected item-total correlations were all $>0.30$, ranging from 0.59 to 0.71 . Squared multiple correlations were all $>0.30$, varying between 0.38 and 0.62 . Cronbach's coefficient alpha did not 


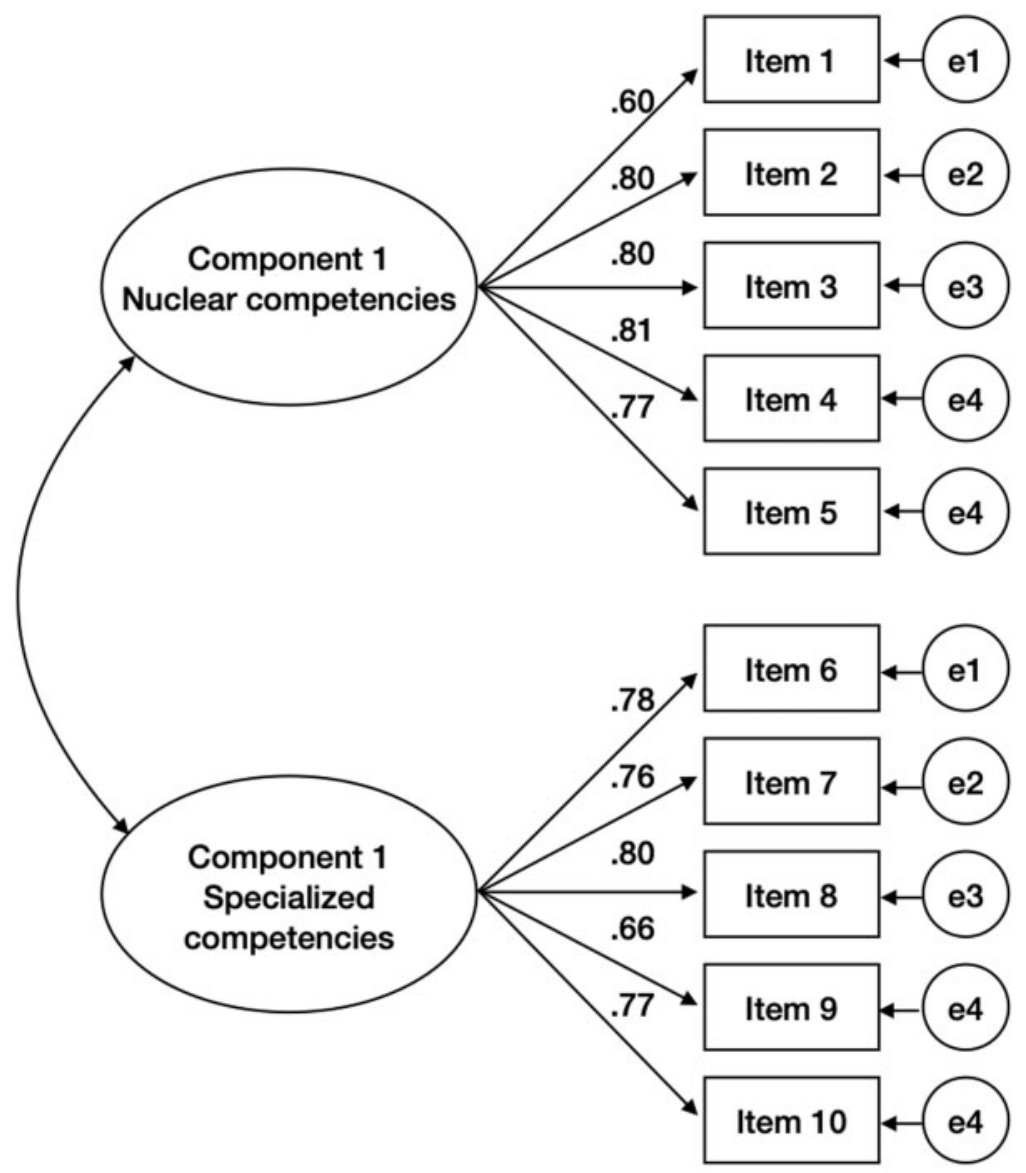

Figure 1: CFA of the GSWCS-II-VETP. Items are numbered in the order presented in Table 2. All standardised regression weights were significant $(p<0.05)$.

Table 2 Model comparisons

\begin{tabular}{|c|c|c|c|c|c|c|c|c|}
\hline \multirow[t]{2}{*}{ Models } & \multirow[t]{2}{*}{ NC } & \multirow[t]{2}{*}{ CFI } & \multirow[t]{2}{*}{$\mathrm{NFI}$} & \multirow[t]{2}{*}{ SRMR } & \multirow[t]{2}{*}{ RMSEA } & \multicolumn{2}{|c|}{$90 \% \mathrm{Cl}$} & \multirow[t]{2}{*}{$\mathrm{AIC}$} \\
\hline & & & & & & $\mathrm{LL}$ & UL & \\
\hline One-factor & 14.088 & 0.841 & 0.831 & 0.034 & 0.157 & 0.145 & 0.169 & 583.09 \\
\hline Two-factor & 5.952 & 0.942 & 0.931 & 0.022 & 0.096 & 0.084 & 0.109 & 244.37 \\
\hline
\end{tabular}

Note. Structural equation modelling was used for the analysis. $\mathrm{CFI}=$ comparative fit index; $\mathrm{NFI}=$ normed fit index; RMSEA = root-mean-square error of approximation; LL, lower limit; UL, upper limit.

increase by deleting any of the GSWCS-II-VETP items. All items loaded significantly $(p<0.001)$, and standardised loadings were $\geq 0.60$, supporting the local fit of the model. Finally, the Cronbach's coefficient 
alpha of the two factors was adequate (Table 3), and we named them 'nuclear competencies' and 'specialised skills'.

\section{Discussion}

The overall aim of this study was to test the fit of the Portuguese version of the GSWCS-II-VETP and explore a bifactor structure and its reliability in a sample of social workers.

The translation into Portuguese followed Hambleton et al. (2005) and International Test Commission (2017) recommendations. Minor inconsistencies were found but expert discussions allowed for the achievement of a linguist equivalent and interpretable version.

CFA results supported a two-factor model following studies that applied factorial analysis to other GSWCS-II domains 'Core Geriatric Assessment Practice Behaviours' and 'Specialised Geriatric Assessment Practice Behaviours' (Bonifas and Simons, 2014). All items showed factorial validity, with significant factor loadings, squared multiple correlations and standardised regression weights for all items were above the criterion thresholds (Hair et al., 2009; Garson, 2013). Moreover, each item loaded significantly on its hypothesised factor. Squared multiple correlations revealed strong associations (Garson, 2013) between items and their respective factors.

Internal consistency of the GSWCS-II-VETP was good, with the Cronbach's alpha coefficient being similar to Tuncay and Duyan (2015) with social work bachelor students.

'Respect diversity among older adult clients, families, and professionals' was the item with the highest mean, both in our study and in the Aiduk (2010) performed with frontline workers at in-home essential services for older people and individuals with disabilities. This same item had the highest mean in the Galambos et al.'s (2014) study with social work students, but only before taking a gerontological social work practice course. After the course, the most endorsed item was 'Respect and promote older adult clients' right to dignity and self-determination'. This finding gives strength to the idea that education programmes potentially change the theoretical perspective regarding old age (Peterson, 1990; Rosen et al., 2000; Damron-Rodriguez et al., 2009).

Notwithstanding, 'Respect diversity ...', 'Address the cultural, spiritual, and ethnic values' and 'Respect ... dignity and self-determination' were the most endorsed items in our study, which did not come as a surprise considering they are expressed in different ethics/deontological codes (Associação dos Profissionais de Serviço Social, 2018; National Association of Social Workers, 2021). Moreover, 'Respect diversity ...,' is also central in the Global Social Work Statement of Ethical Principles (International Federation of Social Workers, 2018). 


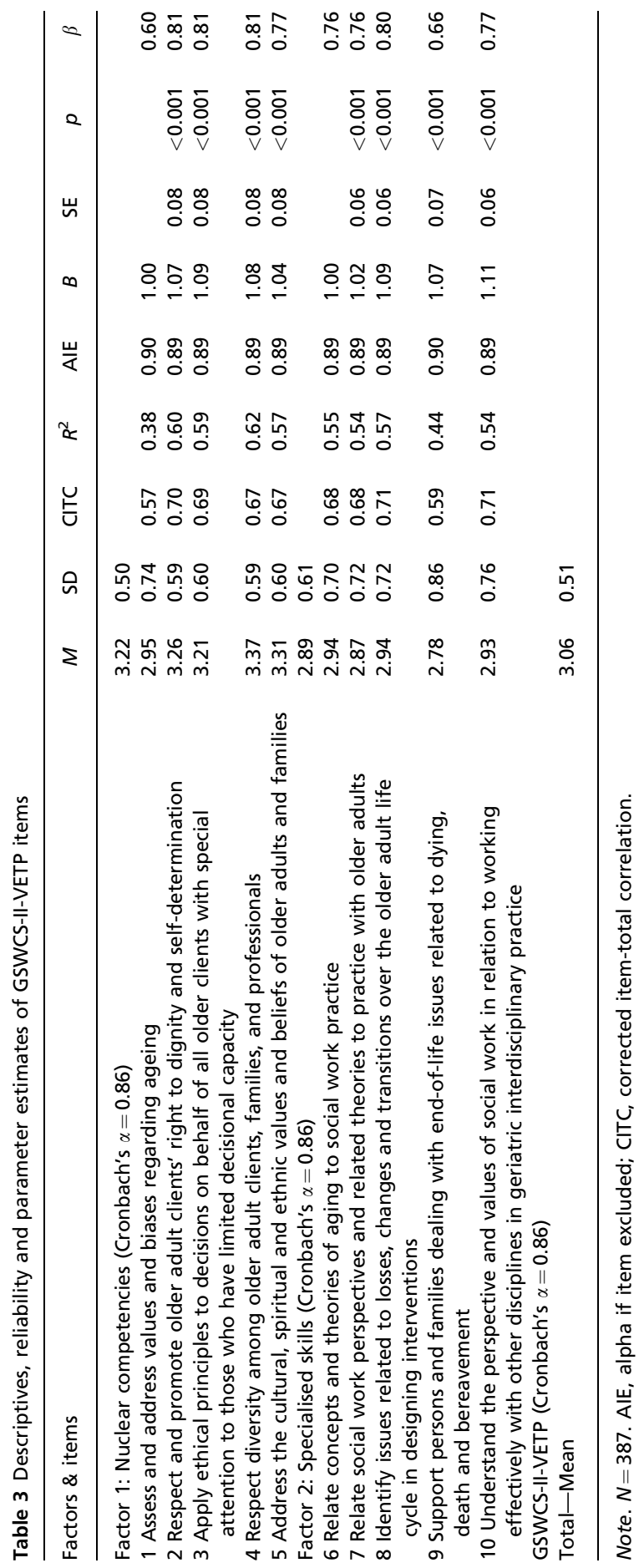


The item that received the lowest score ('Support persons and families dealing with end-of-life issues ...') was not the same as Aiduk's study (2010); 'Relate social work perspectives and related theories ...'), nor that of Galambos et al. (2014) before taking the gerontological course ('Relate concepts and theories of aging to social work practice') and after the course ('Assess and address values and biases regarding aging').

The lower average scores of Aiduk's (2010) study and of Galambos et al. (2014) (pre-course) were obtained in items that refer to theoretical knowledge or conceptual level about ageing. In our study, the less endorsed item refers to a practice level, probably understood as an activity essentially performed by psychologists (Holloway and Taplin, 2013). According to Sormanti (2019), grief, for its characteristics and psychosocial consequences, is a complex issue that, although essential for the gerontological social worker's practise, can be considered a difficult domain to master. Moreover, dealing with end-of-life concerns has become the role of several palliative care services, replacing the once social worker's role (Holloway and Taplin, 2013). The emergence of bureaucratic practices and procedures that structure the professional practice of social work to the detriment of the professional relationship may also contribute to this score. Social work's managerial perspectives emphasise the fulfilment of paperwork, procedures, quick solutions and approaches that eradicate the risk. What seems to have happened is that, instead of facing the realities of social service practice's sociopolitical scenario, policymakers have generated increasingly restrictive procedures and practices (Wilson et al., 2008).

The total score of the GSWCS-II-VETP was comparable to the studies of Aiduk (2010) with 50 front line workers, Galambos and Curl (2013) with 74 graduate-level students and Daniel et al. (2018) with 387 social workers with managerial positions, despite the different characteristics of the respondents.

The two dimensions of GSWCS-II-VETP showed high reliability. Additionally, the nuclear competencies' score was higher than the specialised skills' score. This result was similar to those obtained by Bonifas and Simons (2014) with the dimensions of the 'Assessment' and 'Intervention' subscales of the GSWCS-II. The superiority of selfassessed core competencies probably shows that they are foundational competencies and can be associated with the curricular content of social work courses worldwide. Moreover, although ageing has increasingly become a global reality, specialist knowledge is not spread in the same way as nuclear competencies, strengthening the importance of their inclusion in social work curricula.

Some study limitations and strengths should be addressed. Our findings offer important insights that can show new paths to social work scholars and researchers. We enrolled 534 participants from all over the mainland of Portugal, representing a large population from diverse 
professional categories and leadership functions and different institutional, juridical frameworks. These aspects give the study good generalisability to other social workers' populations implicated with other contexts involving older adults. Moreover, our results constitute a potential gold standard for assessing social work values, ethics and theoretical perspectives in gerontological behaviours.

Regarding limitations, the social worker registrations are not public, and the total numbers are not identified. As such, our study was not probabilistic, and the response rate is not known. We used a web-based survey, which could be affected by self-selection bias, by enlisting participants who were more inclined to share data and more technologically skilled. In contrast, web-based surveys tend to involve respondents more compliant to answer potentially sensitive questions anonymously in electronic format than in the presence of the interviewer (Kays et al., 2012). Moreover, web-based survey data derive from non-probability sampling, which might have introduced some biases. Nonetheless, online survey studies are a quick way to reach more respondents (Szolnoki and Hoffmann, 2013). So, extrapolating our results to the general population of social workers should be made with caution.

In conclusion, this study's findings suggest that social work scholars should include gerontological contents in their curricula and that they could use GSWCS-II-VETP to assess students' grasp of nuclear competencies and specialised skills.

\section{Acknowledgements}

Alexandre Gomes da Silva served as a statistical advisor.

Conflict of interest. No potential conflict of interest was reported by the authors.

\section{References}

Aiduk, T. (2010) 'Geriatric competency, training, and services: Surveying a local aging access point', Undergraduate Review, 6, pp. 8-14.

Associação dos Profissionais de Serviço Social (2018) 'Código Deontológico dos Assistentes Sociais em Portugal', Available online at: https://www.apss.pt/wp-con tent/uploads/2018/12/CD_AS_APSS_Final_APSS_AssembGeral25-10-2018_apro vado_RevFinal.doc-1-converted-1-C\%C3\%B3pia.pdf (accessed September 1, 2020).

Banks, S. (2004) 'Ethical challenges for social work', Intervenção Social, 29, pp. $11-24$.

Bonifas, R. P. and Simons, K. (2014) 'An examination of the factor structure of the Hartford Geriatric Social Work Competency Scale-II Assessment and Intervention subscales', Educational Gerontology, 40(9), pp. 700-12. 
Browne, M. W. and Cudeck, R. (1992) 'Alternative ways of assessing model fit', Sociological Methods \& Research, 21(2), pp. 230-58.

Byrne, B. M. (2016) Structural Equation Modelling with AMOS: Basic Concepts, Applications, and Programming, 3rd edn, New York, NY, Routledge.

Carvalho, I. M. M. D. and Almeida, P. H. D. (2003) 'Família e proteção social', São Paulo em Perspectiva, 17(2), pp. 109-22.

Casimir, A. and Samuel, E. (2015) 'Ethicalization of social work and socialisation of ethics-An African challenge', Open Journal of Political Science, 5(2), pp. 49-57.

Damron-Rodriguez, J. A., Volland, P., Wright, M. E. and Hooyman, N. R. (2009) 'Competency-based education: Implications of the Hartford geriatric social work approach', in Hooyman N. R. (ed), Transforming Social Work Education: The First Decade of the Hartford Geriatric Social Work Initiative, pp. 21-50. Alexandria, VA, Council on Social Work Education Press.

Damron-Rodriguez, J., Lawrance, F. P., Barnett, D. and Simmons, J. (2006) 'Developing geriatric social work competencies for field education', Journal of Gerontological Social Work, 48(1-2), pp. 139-60.

Daniel, F. B., Monteiro, R., Jorge, F. and Álvarez-Pérez, P. (2018) 'Competencias éticas en la práctica profesional de las/los trabajadoras/es sociales con personas mayores', Papers. Revista de Sociologia, 103(3), pp. 423-45.

Daniel, F., Silva, A. and Ferreira, P. (2015) 'Contributions to the discussion on the assessment of the reliability of a measurement instrument', Revista de Enfermagem Referência, IV Série(7), pp. 129-37.

Gabinete de Estratégia e Planeamento do Ministério do Trabalho, Solidariedade e Segurança Social. (2020) 'Carta Social: Rede de Serviços e Equipamentos do Distrito de Coimbra na Area de Intervenção Com Pessoas Idosas nas Respostas Sociais de Centro de dia, Estrutura Residencial Para Pessoas Idosas e Serviço de Apoio Domiciliário', available online at: http://www.cartasocial.pt/index2.php? filtrar $=$ hidden $\&$ foco $=$ cb_valencia\&cod_distrito $=06 \&$ cod_concelho $=0 \&$ cod_freguesia $=0 \&$ cod_area $=21 \&$ cod_valencia $=2101 \& \mathrm{dcf}=06($ accessed July 19,2020$)$

Galambos, C. and Curl, A. (2013) 'Developing gerontological competency: A curriculum approach', Gerontology \& Geriatrics Education, 34(3), pp. 309-21.

Galambos, C., Curl, A. L. and Woodbury, K. (2014) 'Research note - Testing for gerontological competencies: A pilot study', Journal of Social Work Education, 50(1), pp. 191-6.

Gallagher, J. M., Bonifas, R. P. and Warner, E. (2020) 'Geriatric Social Work Competency Scale II: Testing the hypothesised factor structure', Journal of Social Work Education, 56(2), pp. 260-72.

Garson, G. D. (2013) Factor Analysis, Asheboro, NC, Statistical Associates.

Hair, J., Black, B., Babin, B. and Anderson, R. (2009) Multivariate Data Analysis, 7th edn. Upper Saddle River, NJ, Pearson Higher Ed.

Hambleton, R. K., Merenda, P. F. and Spielberger, C. D. (2005) Adapting Educational and Psychological Tests for Cross-Cultural Assessment, Mahwah, NJ, Lawrence Erlbaum Associates Publishers.

Holloway, M. and Taplin, S. (2013) 'Editorial', British Journal of Social Work, 43(2), pp. 203-15.

$\mathrm{Hu}$, L. and Bentler, P. M. (1999) 'Cutoff criteria for fit indexes in covariance structure analysis: Conventional criteria versus new alternatives', Structural Equation Modeling: A Multidisciplinary Journal, 6(1), pp. 1-55. 
Instituto Nacional de Estatística. (2013) 'Censos 2011. Resultados Definitivos. Portugal', available online at: https://censos.ine.pt/xportal/xmain?xpid=CENSOS\& xpgid=ine_censos_publicacao_det\&contexto=pu\&PUBLICACOESpub_boui $=732$ $12469 \&$ PUBLICACOESmodo $=2 \&$ selTab $=$ tab1\&pcensos $=61969554$ (accessed July 19, 2020).

International Federation of Social Workers. (2018) 'Global Social Work Statement of Ethical Principles - International Federation of Social Workers', available online at: https://www.ifsw.org/global-social-work-statement-of-ethical-principles/ (accessed July 19, 2020).

International Test Commission. (2017) The ITC Guidelines for Translating and Adapting Tests. 2nd edn. available online at: www.InTestCom.org (accessed July 19, 2020).

Kays, K., Gathercoal, K. and Buhrow, W. (2012) 'Does survey format influence self-disclosure on sensitive question items?', Computers in Human Behavior, 28(1), pp. 251-6.

Kline, R. B. (2015) Principles and Practice of Structural Equation Modeling, 4th edn. New York, NY, The Guilford Press.

Marsh, H. W., Balla, J. R. and McDonald, R. P. (1988) 'Goodness-of-fit indexes in confirmatory factor analysis: The effect of sample size', Psychological Bulletin, 103(3), pp. 391-410.

Mioto, R. C. T. and Nogueira, V. M. R. (2013) 'Política social e serviço social: Os desafios da intervenção profissional', Revista Katálysis, 16, pp. 61-71.

Nações Unidas - ONU Portugal. (2019) 'Envelhecimento'. Nações Unidas - ONU Portugal, available online at: https://unric.org/pt/envelhecimento/ (accessed July 19, 2020).

National Association of Social Workers. (2020a) 'Aging'. NASW - National Associacion of Social Workers, available online at: https://www.socialworkers.org (accessed July 19, 2020).

National Association of Social Workers. (2020b) 'Code of Ethics Approved by the 1996 NASW Delegate Assembly and Revised by the 2017 NASW Delegate Assembly'. NASW - National Association of Social Workers, available online at: https://www.socialworkers.org (accessed November 16, 2020).

National Association of Social Workers (2021) '2021 Revisions to the NASW Code of Ethics', NASW - National Associacion of Social Workers, available online at: https://www.socialworkers.org (accessed September 16, 2021).

Peterson, D. A. (1990) 'Personnel to serve the aging in the field of social work: Implications for educating professionals', Social Work, 35(5), pp. 412-5.

Reamer, F. G. (2013) 'The evolution of social work ethics: Bearing witness', Advances in Social Work, 15(1), pp. 163-81.

Reamer, F. G. (2017) 'Evolving ethical standards in the digital age', Australian Social Work, 70(2), pp. 148-59.

Rosen, A. L. and Zlotnik, J. L. (2001) 'Social work's response to the growing older population', Generations: Journal of the American Society on Aging, 25(1), pp. $69-71$.

Rosen, A. L., Zlotnik, J. L., Curl, A. L. and St Green, R. G. (2000) CSWE SAGE-SW National Competencies Survey and Report. Alexandria, VA, Council on Social Work Education, Gero-Ed Center, available online at: https://www.cour sehero.com/file/31460637/CSWESAGE-SWNationalCompetenciesSurveyandReportdoc/ (accessed July 19, 2020). 
Rosen, A. L., Zlotnik, J. L. and Singer, T. (2003) 'Basic gerontological competence for all social workers', Journal of Gerontological Social Work, 39(1-2), pp. 25-36.

Scharlach, A., Damron-Rodriguez, J., Robinson, B. and Feldman, R. (2000) 'Educating social workers for an aging society', Journal of Social Work Education, 36(3), pp. 521-38.

Sormanti, M. (2019) 'Bereavement practice'. Oxford Bibliographies. 10.1093/OBO/9780195389678-0117 (accessed July 19, 2020).

Szolnoki, G. and Hoffmann, D. (2013). 'Online, face-to-face and telephone surveys-Comparing different sampling methods in wine consumer research', Wine Economics and Policy, 2(2), pp. 57-66.

Tuncay, T. and Duyan, V. (2015) 'Turkish adaptation of the geriatric social work competency scale in a group of social work bachelor students', Turkish Journal of Geriatrics, 18(1), pp. 60-7.

Vicente, H. T. and Sousa, L. (2012) 'Relações intergeracionais e intrageracionais: A matriz relacional da família multigeracional', Revista Kairós: Gerontologia, 15(11), pp. 99-117.

Ware, J. E. and Gandek, B. (1998) 'Methods for testing data quality, scaling assumptions, and reliability: The IQOLA Project approach. International Quality of Life Assessment', Journal of Clinical Epidemiology, 51(11), pp. 945-52.

West, S. G., Taylor, A. B. and Wu, W. (2012) 'Model fit and model selection in structural equation modelling', Handbook of Structural Equation Modeling, pp. 209-31, York, NY, The Guilford Press New.

Wilson, K., Ruch, G., Lymbery, M., Cooper, A., Becker, S., Brammer, A., Clawson, R., Littlechild, B., Paylor, I. and Smith, R. (2008) Social Work: An Introduction to Contemporary Practice, Essex, England, Pearson Education Limited. 